\title{
Effect of milk protein composition of a model infant formula on the physicochemical properties of in vivo gastric digestates
}

\author{
N. Rafiee Tari, ${ }^{\star}$ M. Z. Fan, $\dagger$ T. Archbold, $\dagger$ E. Kristo, ${ }^{* 1}$ A. Guri, $\ddagger$ E. Arranz, ${ }^{*}$ and M. Corredig ${ }^{*} \ddagger^{2}$ \\ *Department of Food Science, and \\ †Department of Animal Biosciences, University of Guelph, Guelph N1G 2W1, ON, Canada \\ $\ddagger$ Gay Lea Foods Research and Development, Guelph N1H 1J5, ON, Canada
}

\section{ABSTRACT}

We investigated the effect of protein composition and, in particular, the presence of whey proteins or $\beta$-casein on the digestion behavior of a model infant formula using an in vivo piglet model. Three isocaloric diets optimized for piglets were prepared with the same concentrations of protein. For protein source, 1 diet contained only whey proteins and 2 contained a casein: whey protein ratio of 40:60 but differed in the amount of $\beta$-casein. To obtain the desired protein compositions, skim milk was microfiltered at 7 or $22^{\circ} \mathrm{C}$, and retentates and permeates were combined with whey protein isolate. The diets were optimized to the nutritional needs of the piglets and fed to 24 newborn piglets for $18 \mathrm{~d}$. Eight piglets were also fed ad libitum with sow milk and considered only as reference (not included in the statistical analysis). The study was carried out in 2 blocks, killing the animals 60 and 120 min after the last meal. All gastric contents, regardless of diet, showed a wide range of $\mathrm{pH}$. Postprandial time did not affect the $\mathrm{pH}$ or physical properties of the gastric digesta. The digesta from whey protein-casein formulas showed significantly higher viscosity, a higher storage modulus, and a denser microstructure than digesta obtained from piglets fed whey protein formula. The $\beta$-casein: total casein ratio at the level used in this study did not significantly affect the physical and chemical properties of the stomach digestate. Although caseins showed extensive gastric hydrolysis, whey proteins remained largely intact at both postprandial times. The results indicate that the presence of different concentrations of milk proteins can be critical to the digestion properties of the food matrix and may affect the nutritional properties of the components.

Key words: milk protein composition, $\beta$-casein, model infant formula, in vivo digestion, piglet model

Received May 28, 2017.

Accepted November 27, 2017.

${ }^{1}$ Current address: Parmalat Canada, London, ON, Canada.

${ }^{2}$ Corresponding author: mcorredi@uoguelph.ca

\section{INTRODUCTION}

It is established that beyond individual nutrient content, the compositional, physical, and structural properties of a food matrix can affect its digestion kinetics and physiological properties (Turgeon and Rioux, 2011). In particular, the kinetics of protein degradation during digestion and subsequent amino acid release and absorption can be influenced by food matrix structure and protein composition (Turgeon and Rioux, 2011; Le Feunteun et al., 2014). The gastric phase is a critical stage in the digestion process, not only because of its role in delivering the digesta to the duodenum and regulating intestinal digestion but also because protein hydrolysis begins in this stage.

Dairy products are of interest in the study of how different matrices can affect digestion and nutrient absorption kinetics, because of their widespread consumption in a variety of forms and the presence of different matrices with similar composition depending on the processing history of the product. In the gastric stage, dairy products have shown different digestion properties and transit rates, depending on factors such as composition, physical properties, and processing history (Boirie et al., 1997; Le Feunteun et al., 2014; Ye et al., 2016).

The 2 main milk protein groups - caseins and whey proteins (WP) - show very distinct digestion behaviors. Many digestion studies, mostly in vitro, have been carried out to see how these milk proteins affect protein digestion kinetics and extent of hydrolysis, gastric emptying rate, satiety, the fate of peptides and AA in the intestinal system, synthesis of gastrointestinal hormones, and other physiological aspects of the gut (see, for example, Boirie et al., 1997; Hall et al., 2003; Chatterton et al., 2004; Bouzerzour et al., 2012; Perrella et al., 2015).

Caseins are known to form a coagulated mass during gastric digestion, thus remaining in the stomach longer and being slowly absorbed. Casein micelles are known to form an aggregated gel as a result of a combined effect of proteolysis and acidification (Donato et al., 
2007). Proteases such as pepsin cause milk coagulation by hydrolyzing $\kappa-\mathrm{CN}$. The decrease in $\mathrm{pH}$ and protein hydrolysis cause a significant decrease in the electrostatic and steric stabilizing layer of the protein particles, resulting in the formation of a protein network. In the gastric environment, casein micelles coagulate due to low $\mathrm{pH}$ and pepsin activity (Tam and Whitaker, 1972).

Whey proteins (WP), particularly $\beta$-LG and $\alpha$-LA, are known to be rapidly digested and participate in building of muscle mass, as they remain soluble in the stomach and pass more rapidly toward the intestine. Differences in the composition or ratio of WP to caseins in milk matrices can lead to different delivery rates for peptides and AA (Boirie et al., 1997; Rioux and Turgeon, 2012). Whey proteins have also been shown to induce higher satiating effects than caseins because of their faster gastric transit and higher postprandial plasma AA concentration (Boirie et al., 1997; Hall et al., 2003). In vitro digestion studies have demonstrated that the casein:WP ratio pays an important role in imparting different physicochemical properties to a yogurt matrix in the stomach, and that a low WP ratio causes lower viscosity and a greater extent of disruption of the gastric mass compared with a low casein:WP ratio (Rioux and Turgeon, 2012). This effect was attributed to differences in $\beta-\mathrm{LG} / \kappa-\mathrm{CN}$ complexes and the presence of denatured WP aggregates in the fermented dairy matrix, ultimately affecting pepsin activity.

The peptides generated from caseins and WP during digestion have been shown to exert a wide range of physiological effects in the body (Korhonen and Pihlanto, 2006). It is therefore imperative that the properties of the food matrix during gastrointestinal transit be controlled, as they will affect the manner in which milk proteins are digested and absorbed, ultimately affecting their role in the gut's physiological responses. Comprehensive in vivo studies need to be carried out, focusing on the structure of the digesta of a milk matrix containing the same protein concentration but different milk protein composition. Such studies will lead to a better understanding of how the composition of the milk proteins may affect the physical and chemical properties of dairy matrices during digestion. This is particularly important for infant formula and nutritional milk beverages for all stages of life.

Protein compositional dissimilarities are known to exist between milk of different species. Caseins make up approximately $80 \%$ of the total protein in bovine milk but only $40 \%$ in mature human milk (Thompkinson and Kharb, 2007). Moreover, the major casein protein in human milk is $\beta-\mathrm{CN}$, which makes up about $65 \%$ of total casein, but only up to $35 \%$ in bovine casein micelles (Park and Haenlein, 2006a). Alternatively, WP comprise about $20 \%$ and $60 \%$ of bovine and human milk protein, respectively. Sow milk contains 7 to $8 \%$ milk fat and 5 to $7 \%$ protein, depending on lactation time and breed, with caseins making up about $55 \%$ of the total protein in mature milk (Park and Haenlein, 2006b; Theil and Hurley, 2016). The nutritional relevance of such differences is not fully understood. A recent in vivo animal trial suggested that $\beta-\mathrm{CN}$ might be of physiological significance because some bioactive peptides derived from $\beta-\mathrm{CN}$ were recovered in the small intestine at later stages of digestion and in larger concentrations than those originating from the other caseins (Bouzerzour et al., 2012). Furthermore, previous studies showed some degree of resistance of human milk $\beta-\mathrm{CN}$ at the gastric $\mathrm{pH}$ of infants $(\mathrm{pH}$ of about 4; Chatterton et al., 2004). Little is known about whether different ratios of $\beta$-CN in a bovine milk-based product modulate digestive or physiological behaviors.

The objective of this study was to assess the effect of protein composition, and in particular, the presence of $\mathrm{WP}$ and ratio of $\beta-\mathrm{CN}$, on the digestion behavior and structure of the gastric digesta in a model infant formula. A piglet model was used because it is an established model for human infant nutrition and digestion, due to the morphological and physiological similarities between its gastrointestinal and digestive tract and that of humans (Miller and Ullrey, 1987). This model has been used to study different aspects of digestion in human infants (Darragh and Moughan, 1995; Bouzerzour et al., 2012). Three diets optimized for the energy and nutritional requirements of piglets were prepared with the same concentrations of protein and ME. One formula contained only WP as the protein source and the other 2 contained WP and caseins at a ratio of 60:40, with one being higher and one lower in $\beta-\mathrm{CN}$ concentration. A better understanding of the effect of protein composition in dairy matrices on the digestion behavior of the matrix itself will help in the development of food products with improved nutritional functionalities.

\section{MATERIALS AND METHODS}

\section{Milk Fractionation}

To obtain modified protein ratios, skimmed bovine milk (Crown Dairy Ltd., Canada) was microfiltered using an asymmetrical polyethersulfone BTS 80 membrane (SmartFlow Technologies Inc., Apex, NC) mounted on a plate-and-frame filtration system (ConSep 7000 series, SmartFlow Technologies Inc.) at either 4 to $7^{\circ} \mathrm{C}$ or at 22 to $25^{\circ} \mathrm{C}$. Using different temperatures of filtration allowed different retention of $\beta-\mathrm{CN}$, allow- 
Table 1. Chemical composition of the 3 model formulas ${ }^{1}$

\begin{tabular}{lccc}
\hline Item & WP-based & Low $\beta$-casein & High $\beta$-casein \\
\hline DM (\%) & 9.78 & 9.78 & 9.78 \\
Protein (\%) & 2.81 & 2.80 & 2.80 \\
Crude fat (\%) & 0.92 & 0.90 & 0.90 \\
Lactose (\%) & 5.47 & 5.40 & 5.40 \\
Added minerals/vitamins (\%) & 0.65 & 0.45 & 0.45 \\
ME (kcal/kg) & 360 & 360 & $600: 40$ \\
WP:casein ratio & $100: 0$ & 0.35 & 0.48 \\
$\beta$-Casein (\%) & - & 12.5 & 17.1 \\
$\beta$-Casein (g/100 g of protein) & - & &
\end{tabular}

${ }^{1}$ Isocaloric diets containing whey protein (WP) only or WP and $\beta$-casein at a low or high level.

ing us to obtain permeates with different $\beta-\mathrm{CN}$ :WP ratios. The mechanism of temperature dissociation of $\beta-\mathrm{CN}$ from the casein micelle is well described in the literature (Creamer et al., 1977), as is the exploitation of this principle to create microfiltered permeates of different compositions (Holland et al., 2011). Diafiltration was applied, keeping the trans-membrane pressure at a maximum of $69 \mathrm{kPa}$. When a $2 \times$ concentration of retentate was reached (based on measured volume of collected permeate), the permeate was collected, its volume was replaced with deionized water, and filtration was run again to collect the retentate. Permeate contained about $0.5 \%$ protein, mostly $\mathrm{WP}$ and some $\beta-\mathrm{CN}$, whereas the retentate with $5.5 \%$ protein contained caseins but was depleted of WP. Gel electrophoresis analysis confirmed the partial transmission of $\beta$-CN into the permeate of the cold milk compared with that from the warm milk, which contained $\beta-\mathrm{CN}$ concentrations below the limits of detection (results not shown). In total, about $900 \mathrm{~L}$ of skim milk was filtered and the first permeate and second retentate were collected for use in making the model infant formula.

\section{Formula Composition}

The permeates of the cold and warm microfiltration runs were mixed with the retentates of the warm and cold microfiltration runs, respectively. This resulted in the greatest difference in $\beta$-CN amount of the 2 mixtures. Other ingredients - whey protein isolate $90 \%$ and lactose (Leprino Foods, Denver, CO), soybean oil, vitamins and minerals (Sigma Aldrich, St. Louis, MO; and Grober Nutrition, Cambridge, ON, Canada) - and deionized water were added to the permeate/retentate mixtures as calculated. The final formulas were HTST pasteurized and homogenized by using a pilot-plant scale system (UHT/HTST Lab-25 DH, Microthermics Inc., Raleigh, NC). Milk was preheated to $60^{\circ} \mathrm{C}$, homogenized (13.8 and 3.4 MPa for the first and second stages, respectively), and pasteurized at $72^{\circ} \mathrm{C}$ for $30 \mathrm{~s}$.
The formula was packed in 1-L bottles and stored frozen until required. On the day of consumption, samples were thawed at $4^{\circ} \mathrm{C}$, homogenized, and administered to the piglets. The composition of the diets was similar (Table 1) and the treatments were isocaloric. It is important to note that, despite the same composition of macronutrients in our formulas, different ratios of WP and caseins affect the AA composition. The formula with the higher $\beta$-CN level will contain a higher proportion of phosphorylated AA (Korhonen and Pihlanto, 2006), whereas the WP-based formula will contain a higher proportion of branched-chain AA, including leucine, valine, and isoleucine (Sah et al., 2016). The difference in protein composition will also affect the distribution of peptides released during digestion (Korhonen and Pihlanto, 2006). After processing, samples were used only if they met the following microbiological standards: total viable cell count $(<10,000 \mathrm{cfu} / \mathrm{mL})$, total coliforms $(<10 \mathrm{cfu} / \mathrm{mL})$, and Escherichia coli (absent in $1 \mathrm{~mL}$ of sample). Samples were plated onto Aerobic Plate Count and E. coli/coliform Petrifilms (results not shown).

\section{Animals, Feeding, Euthanasia, and Collection of Digesta Samples}

All animal trials were approved by the University of Guelph's Animal Care Committee (UG AUP 3370) and were conducted in compliance with the Canadian Council of Animal Care (CCAC) guidelines (https:// www.ccac.ca/en/standards/guidelines). Within the animal welfare mandate, the committee also reviewed the statistical design of the study; that is, the number of animals required for the study. The piglet study was conducted at the University of Guelph, in the Animal Science facility. Thirty-two newborn crossbred (York $\times$ Landrace $\times$ Duroc) piglets from Arkell Swine Research Station (University of Guelph, ON, Canada) were used, including equal numbers of males and females. The study was carried out in 2 blocks of 16 piglets, con- 
sistent with other literature studies (Kim et al., 2009; Chatelais et al., 2011). In each block, 12 piglets were randomly assigned to 3 diet groups of 4 , with each group including 2 males and 2 females, individually housed in metabolic cages, and fed on a consistent schedule, from 3 to $21 \mathrm{~d}$ of age. Body weights of the piglets were recorded daily, and feed allowance was calculated accordingly. The isocaloric formula was administered to the piglets in liquid form, at a rate of $60 \%$ of the animals' BW. The experimental design was a randomized block design with a $3 \times 2$ factorial arrangement of 3 diets and 2 sacrifice times (60 and $120 \mathrm{~min}$ ) after the last meal. Eight piglets (4 in each block) remained in the farm with their sows, for comparison of animal behavior and physiological factors such as stomach $\mathrm{pH}$. The digestion behavior and structure of the gastric contents were not statistically analyzed with the other formula groups because postprandial time could not be controlled in the sow-fed group.

At $21 \mathrm{~d}$ of age, animals were anesthetized with inhaled isofluorane and killed by injection of pentobarbital through the cardiac puncture. The last meal volume was based on BW and feeding time, and the schedule of euthanizing was followed accurately to ensure collection at 2 postprandial times - 60 and $120 \mathrm{~min}$. Digesta were removed from stomach upon euthanizing the piglets to determine physicochemical properties. $\mathrm{pH}$, rheological properties, and microstructure of the gastric curd were determined on fresh samples within 20 min. Furthermore, samples of gastric digesta were flash-frozen in liquid nitrogen and stored at $-80^{\circ} \mathrm{C}$ until further study of protein hydrolysis. In addition, a portion of the gastric clots was freeze-dried to measure the nitrogen content as ratio of the DM.

\section{Rheological Properties}

Rheological measurements were conducted immediately after sampling on fresh gastric clots, and results were obtained within $20 \mathrm{~min}$, to minimize structural changes. The measurements were then carried out at $37^{\circ} \mathrm{C}$.

The apparent viscosity of each digesta sample was measured as a function of shear rate of 0.01 to $300 \mathrm{~s}^{-1}$. For the frequency sweep experiment, tests were conducted between 0.1 and $100 \mathrm{~Hz}$, with 5 measurement points for each decade. A controlled strain rheometer (MCR 301, Anton Paar GmbH, Ostfildern, Germany) equipped with a Peltier temperature controller and a parallel plate geometry (PP50, d $=50 \mathrm{~mm}$, Anton Paar) was used. Frequency sweep tests were performed and storage modulus $\left(\mathrm{G}^{\prime}\right)$ and loss modulus $\left(\mathrm{G}^{\prime \prime}\right)$ were measured at a frequency of 0.1 to $100 \mathrm{~Hz}$ at $37^{\circ} \mathrm{C}$, fol- lowed by measurement of the viscosity of the gastric clots over a shear rate range of 0.01 to $300 \mathrm{~s}^{-1}$. The gap between the plates was set between 1 and $3 \mathrm{~mm}$, because of the particle size of the samples, and the normal force was kept constant at $1 \mathrm{~N}$ for 3 min before measurement.

\section{Microstructure}

The microstructure of the fresh gastric clots obtained from the piglets' stomachs was studied using a confocal laser scanning microscope (Leica TSC SP5, Leica Microsystems CMS GmbH, Mannheim, Germany). A small portion of gastric digesta was mixed with $0.2 \%$ (wt/vol) fluorescent dye rhodamine B (excitation and emission wavelengths of 543 and $625 \mathrm{~nm}$, respectively) to stain the protein, placed on a concave confocal microscope slide, covered with a coverslip, and examined with a $63 \times$ magnification lens. The results shown are representative of at least 12 confocal images taken for each piglet.

\section{Protein Characterization}

Total protein in the final product as well as in the digesta was measured as a function of the digestion time. Total nitrogen contents of the gastric digesta were determined by Dumas method (Leco Co., St. Joseph, MI) on freeze-dried samples.

The amount of $\beta-\mathrm{CN}$ in the samples was measured by ion-exchange chromatography as previously reported (Holland et al., 2010). Milk protein fractions in samples were separated by chromatography (AKTA, 900 Series, GE Biosciences, Baie d'Urfé, Quebec, Canada) using a cation-exchange column (HP-SP, GE Biosciences), and eluted with $0.2 \mathrm{M}$ sodium acetate, $6 \mathrm{M}$ urea buffer at $\mathrm{pH} 3.5$, with a gradient of $\mathrm{NaCl}$. Suckling pig digestion was not analyzed, as it is not comparable to the treatments in terms of composition (Park and Haenlein, 2006b).

Digesta samples were analyzed by SDS-PAGE. In addition to freeze-dried samples, the flash frozen mixed stomach contents, consisting of both gastric curd and juice, were tested to evaluate the presence of undigested acid-soluble protein. In this case, the undigested formulas and gastric digesta samples were thawed, centrifuged at $13,000 \times g$ for $10 \mathrm{~min}$, and then diluted with distilled water according to the original measured total $\mathrm{N}$ content. A total of $25 \mathrm{ng}$ of protein was loaded in each well. Samples were treated with $2 \times$ Laemmli sample buffer (Bio-Rad Laboratories, Hercules, CA) and 2-mercaptoethanol, and heated at $95^{\circ} \mathrm{C}$ for $5 \mathrm{~min}$ with shaking. In the case of freeze-dried samples, 5 
$\mathrm{mg}$ of sample was mixed with $0.5 \mathrm{~mL}$ of sample buffer. After cooling to room temperature, $5 \mu \mathrm{L}$ of each sample was loaded quickly to $12 \%$ Mini-Protein TGX precast protein polyacrylamide gels (Bio-Rad Laboratories), which were run at a constant voltage of 200 $\mathrm{V}$ in a Bio-Rad mini-protein electrophoresis system (Bio-Rad Laboratories). An SDS-PAGE molecular weight standard (Broad Range, Bio-Rad Laboratories), pure $\beta$-CN (Sigma-Aldrich), and WPI 90 (whey protein isolate with $\sim 90 \%$ protein; Leprino Foods) were used as molecular weight markers. After each run, the gels were immediately stained for 30 min using Coomassie Blue R-250 and then destained with a solution of $45 \%$ ultrapure water, $45 \%$ methanol, and $10 \%$ acetic acid. A Sharp JX-330 scanner (Amersham Biosciences, Quebec, Canada) was used to scan the gels.

\section{Statistical Analysis}

Data were analyzed using ANOVA and Tukey's multiple comparison test with SigmaPlot 12.5 (Systat Software Inc., San Jose, CA). Differences were considered significant at $P<0.05$.

\section{RESULTS AND DISCUSSION}

Piglet growth performance, eating behavior, feed intake, and health status were continuously monitored throughout the study, along with gut inflammatory and hormonal responses; these results will be published in a future study. Piglets showed normal behavior judged by absence of clinical symptoms. For consistency in feeding conditions before collecting samples, the last meal was given to piglets 20 min before the calculated postprandial time. Thus, when the animals were killed $60 \mathrm{~min}$ (120 $\mathrm{min}$ ) after their last meal, they were given food $80 \mathrm{~min}(140 \mathrm{~min})$ prior, ensuring that all the piglets finished their last meal. The piglets did not have access to water for at least $4 \mathrm{~h}$ before the last meal.

\section{$\mathrm{pH}$ of the Gastric Digesta}

Figure 1 summarizes the variation in $\mathrm{pH}$ of the gastric digesta obtained from the stomach at postprandial times 60 and $120 \mathrm{~min}$. The $\mathrm{pH}$ of the digesta collected from piglets fed ad libitum is also indicated as reference. In general, the $\mathrm{pH}$ of all gastric digesta of the formula-fed piglets was in the range of 4.4 to 5.8 , with no significant difference observed between the diets or with the time of digestion, despite the wide range observed within each group of piglets. The $\mathrm{pH}$ values measured in the gastric digesta are in good agreement with previous in vivo research results on piglets, which reported a $\mathrm{pH}$ of 4.5 after 30 - and 90 -min digestion of

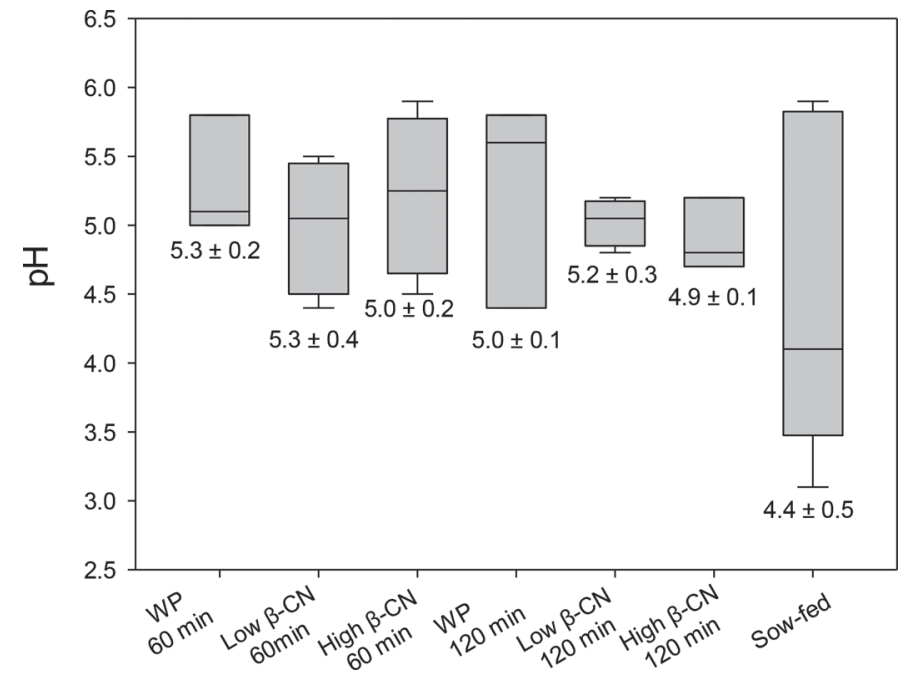

Figure 1. pH of stomach contents at 60 and 120 min after the last meal $(\mathrm{n}=4)$. Gastric $\mathrm{pH}$ for sow-fed piglets was the average of 2 blocks $(n=8)$ and used only as a reference (not included in statistical analysis). Piglets were fed with sow milk, whey protein (WP)based formula, or WP-casein based formulas containing high or low $\beta-\mathrm{CN}$ :total casein ratio. Values are means \pm standard error of means; the black line within the block represents the median. There was no significant difference between $\mathrm{pH}$ of different diet groups $(P>0.05)$.

dairy formula (Bouzerzour et al., 2012). In addition, a gastric $\mathrm{pH}$ of 5.24 was measured $1 \mathrm{~h}$ after ingestion of bovine milk (Moughan et al., 1991). This relatively high gastric $\mathrm{pH}$ during the studied digestion times despite the continuous endogenous secretion can be explained by slow gastric emptying of milk proteins and the high buffering capacity of the formula. It has been suggested that the activity of pepsin may be limited in the stomach of infants due to the buffering capacity of milk, which increases $\mathrm{pH}$ (Mason, 1962). Mean infant gastric $\mathrm{pH}$ has been previously reported in the range of 4 to 6.4, which can be far from the $\mathrm{pH}$ optimum for gastric pepsin activity (Mason, 1962; Chatterton et al., 2004).

The $\mathrm{pH}$ value of gastric content for suckling piglets is included in Figure 1 as a comparison with the formulafed animals. The values measured ranged from 3.1 to 5.8 , with a wider range and a lower minimum $\mathrm{pH}$ than that of the formula-fed piglets. This difference may be caused by the ad libitum feeding and the differences in physiological factors and composition of sow milk. Due to lack of control over postprandial time before killing this group, as well as the difference in the sow milk composition, the $\mathrm{pH}$ data measured in this group were not statistically analyzed.

\section{Protein Characterization}

The total nitrogen present in the gastric digesta on a DM basis is reported in Figure 2. The total ni- 


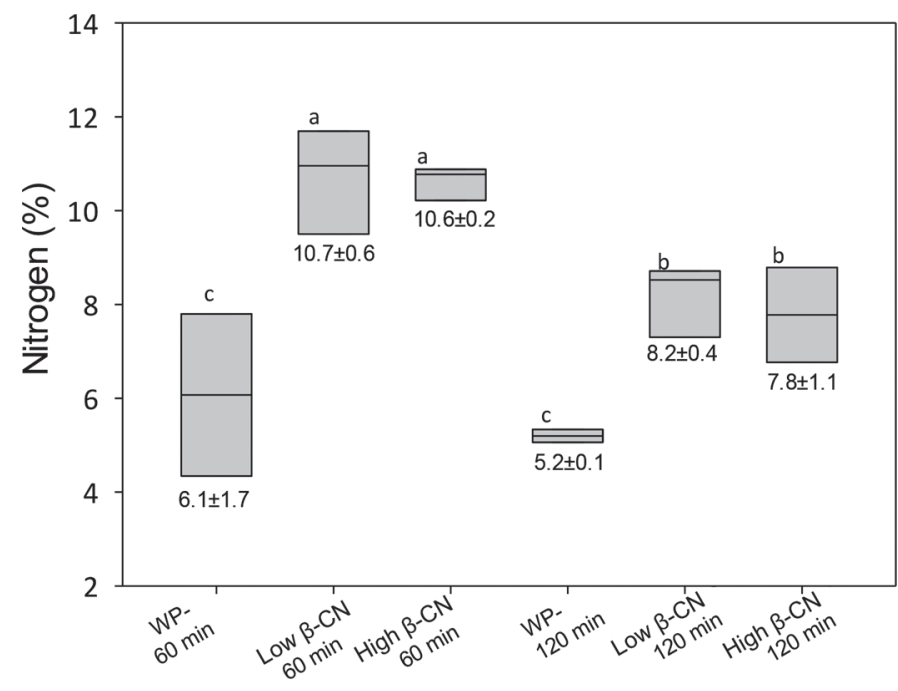

Figure 2. Nitrogen content of the digesta, based on DM, obtained from the stomach of piglets at 60 and 120 min after the last meal (n $=4$ ). Piglets were fed with sow milk, whey protein (WP)-based formula, or WP-casein based formulas containing high or low $\beta$-CN:total casein ratio. Values are means \pm standard error of means; the black line within the block represents the median. Different letters (a, b, c) represent significant differences between treatment groups at $P<0.05$.

trogen concentration of the gastric contents obtained from piglets fed WP-based formula was significantly lower than that obtained from piglets fed WP-casein formula. There were no differences between the $2 \mathrm{WP}-$ casein formulas, regardless of $\beta$-CN content, at either 60 or 120 min postprandial. However, for these 2 treat- ments, there was a significant difference in the nitrogen content between 60 and $120 \mathrm{~min}$, indicating a change in the composition of the digesta over time. This is consistent with previous work that showed a decreasing trend of total nitrogen with increasing digestion time in the stomachs of piglets fed a WP-casein model formula (Bouzerzour et al., 2012). However, a comparison of literature results is challenging because the values will depend on the sampling method. In the current study, the samples consisted of the clotted gastric mass. On a dry basis, the nitrogen concentration of the gastric digesta of WP formula was significantly lower than that of the WP-casein formula, with no differences in postprandial time. This suggested a different composition of the gastric clot, higher in lipids and carbohydrates for WP than for WP-casein formula. Gastric emptying differs with different protein concentrations and, more importantly, with type of protein (Perrella et al., 2015). These results indicated faster digestion of the protein in the WP formula, because WP remains soluble and reaches the duodenum faster than caseins (Boirie et al., 1997).

Figure 3 shows the polypeptide composition of the initial formula and soluble phase of the gastric digesta from the model formula, as measured by SDS-PAGE under reducing conditions. Regardless of treatment, the 2 main whey proteins, $\beta-\mathrm{LG}$ and $\alpha-\mathrm{LA}$, were the major undigested proteins in the soluble fraction, even in gastric samples collected $120 \mathrm{~min}$ postprandial. In the WP-casein formula, regardless of postprandial time, no

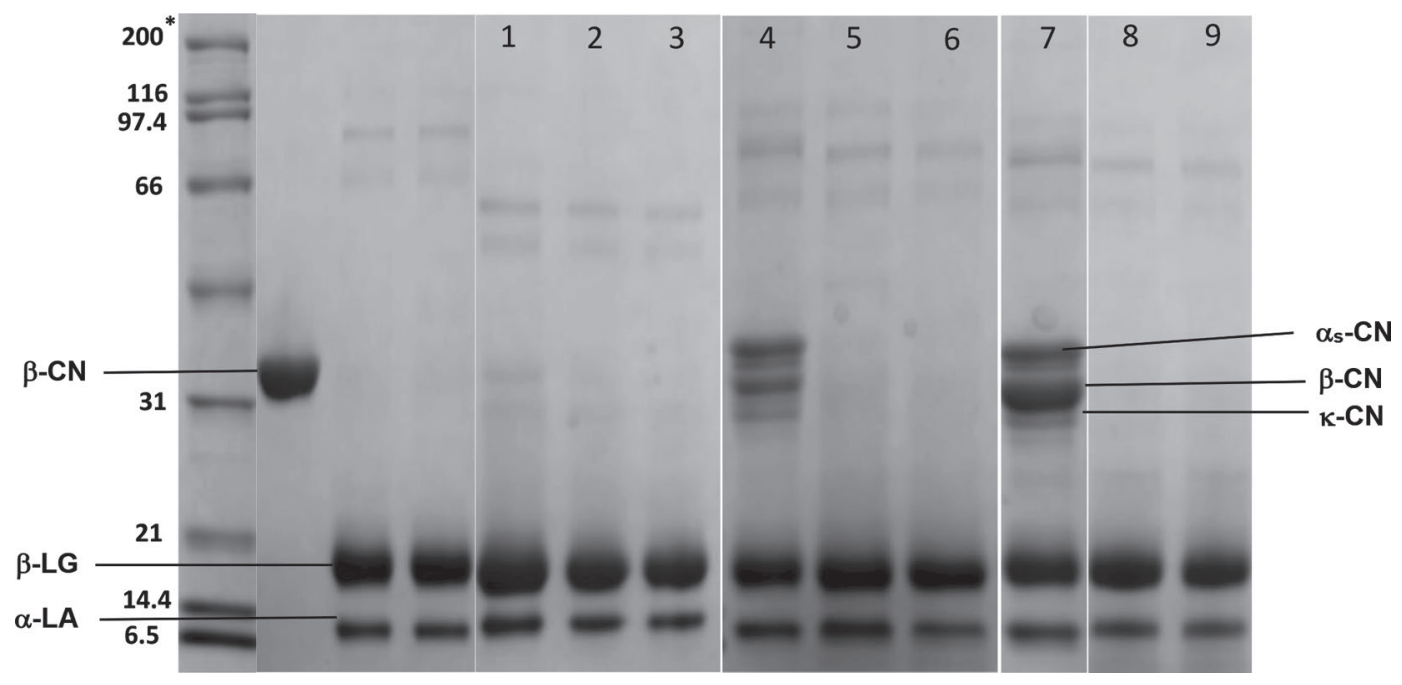

Figure 3. Sodium dodecyl sulfate-PAGE under reducing condition of initial formula and soluble phase of the gastric digesta collected at postprandial times of 60 and $120 \mathrm{~min}$. Left-most lanes = molecular weight of standard proteins and pure $\beta-\mathrm{CN}, \beta-\mathrm{LG}$, and $\alpha-\mathrm{LA}$; lanes $1-3=$ whey protein (WP)-based formula; lanes $4-6=\mathrm{WP}$-casein based formula containing low $\beta$-CN:total casein ratio; lanes 7-9 $=$ WP-casein based formula containing high $\beta$-CN:total casein ratio. Lanes $1,4,7=$ initial formula as fed to the piglets; lanes $2,5,8=$ digesta after 60 min; lanes 3, 6, 9 = digesta after 120 min. All samples were loaded at about $25 \mathrm{ng}$ of protein (based on nitrogen analysis). 


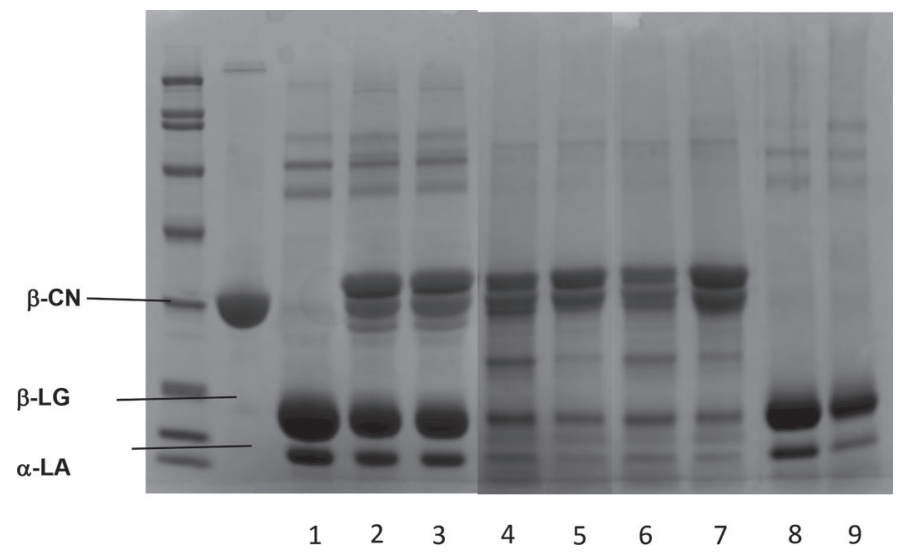

Figure 4. Sodium dodecyl sulfate-PAGE under reducing condition of initial formula and gastric digesta collected at 60- and 120-min postprandial times. Left-most lane $=$ molecular weight of standard proteins; lanes 1, 8, 9 = whey protein (WP)-based formula; lanes 2, 4, $5=\mathrm{WP}$-casein based formula containing low $\beta$-CN:total casein ratio; lanes 3, 6, $7=\mathrm{WP}$-casein based formula containing high $\beta$-CN:total casein ratio. Lanes $1-3=$ initial formula as fed to the piglets; lanes 4, 6, $8=$ digesta after $60 \mathrm{~min}$; lanes 5, 7, $9=$ digesta after $120 \mathrm{~min}$.

residual soluble caseins remained after gastric digestion, although a similar amount of undigested WP was present. The absence of casein from the soluble phase is consistent with the presence of an enzymatic and acidic casein coagulum (Dalgleish and Corredig, 2012). It is important to note that the supernatants were all adjusted to comparable levels of original protein.

Figure 4 illustrates the electrophoretic pattern for the initial formula and the clotted digesta from freezedried samples. In this case, samples were loaded based on solids, and a higher protein amount was present in the WP-casein clot compared with WP formula digesta (Figure 2). We detected some differences in the amount of residual protein digested at 60 or 120 min postprandial. In the case of WP-casein formula, regardless of the $\beta$-CN amount, an intermediate band was observed at $\sim 20 \mathrm{kDa}$, suggesting the presence of intermediate casein peptides. The significant hydrolysis of caseins is in agreement with an in vivo study that followed the fate of milk protein peptides during digestion of a WPcasein formula (Bouzerzour et al., 2012). Furthermore, it has been reported (Ye et al., 2016) that $\alpha_{S^{-}} \mathrm{CN}$ and $\beta-\mathrm{CN}$ resist in vitro gastric digestion of skim milk; $\alpha_{S^{-}}$ $\mathrm{CN}$ and $\beta-\mathrm{CN}$ as well as $\alpha-\mathrm{LA}$ and $\beta-\mathrm{LG}$ were recovered after in vitro digestion of skim milk (Ye et al., 2016). This was not the case in the digestates analyzed in Figure 4.

After 120 min of digestion, more $\alpha$-LA was digested in all formulas, consistent with Mahé et al. (1996), who reported that although casein empties from the stomach mainly as peptides, $\beta$-LG empties mainly as intact protein. In vitro, $\alpha-\mathrm{LA}$ is hydrolyzed faster than $\beta-\mathrm{LG}$ during gastric digestion of unheated skim milk (Ye et al., 2016). Other reports showed partial resistance of WP to degradation during in vivo gastric digestion in piglets (Bouzerzour et al., 2012) and in rats (Miranda and Pelissier, 1983), consistent with the findings reported in Figures 3 and 4.

\section{Structural Characterization of the Gastric Digesta}

Figure 5 shows the visual appearance of the digesta sampled 60 min after the piglets' last meal for the 3 treatment groups. The volume and appearance of the digesta did not change in the 2 treatment blocks $(60$ and $120 \mathrm{~min}$ ), and only the images of samples taken after 60 min are shown in Figure 5. All digesta showed a gel-like structure and an aggregated appearance. The aggregates derived from the stomach digesta of WP formula showed a more fragmented structure than those obtained from the WP-casein mixtures, which showed a similar appearance regardless of $\beta-\mathrm{CN}$ content. It is known that the caseins in milk form a coagulum at low pH (Dalgleish and Corredig, 2012) and in the pres-
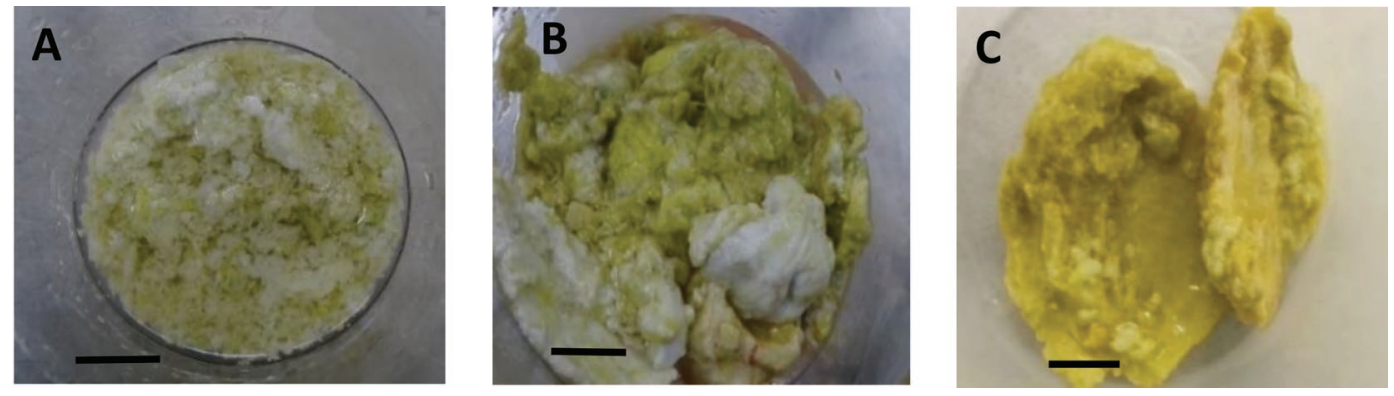

Figure 5. Images of digesta formed during the gastric digestion in piglets fed with (A) whey protein (WP)-based formula; (B) WP-casein based formula containing low $\beta$-CN:total casein ratio; and (C) WP-casein based formula containing high $\beta$-CN:total casein ratio formula. Samples were taken after $60 \mathrm{~min}$ from last meal. Scale bars represent $1 \mathrm{~cm}$. Color version available online. 
ence of aspartic proteases such as pepsin (Tam and Whitaker, 1972). It was also shown in vivo that $\kappa$-CN is also hydrolyzed by pepsin to para- $\kappa-\mathrm{CN}$, which accelerates destabilization of the casein micelles and their coagulation. However, as shown in Figure 4, the SDS-electrophoretic analysis of the WP-casein digesta demonstrated that the network was composed of WP and caseins, with intact caseins present even $120 \mathrm{~min}$
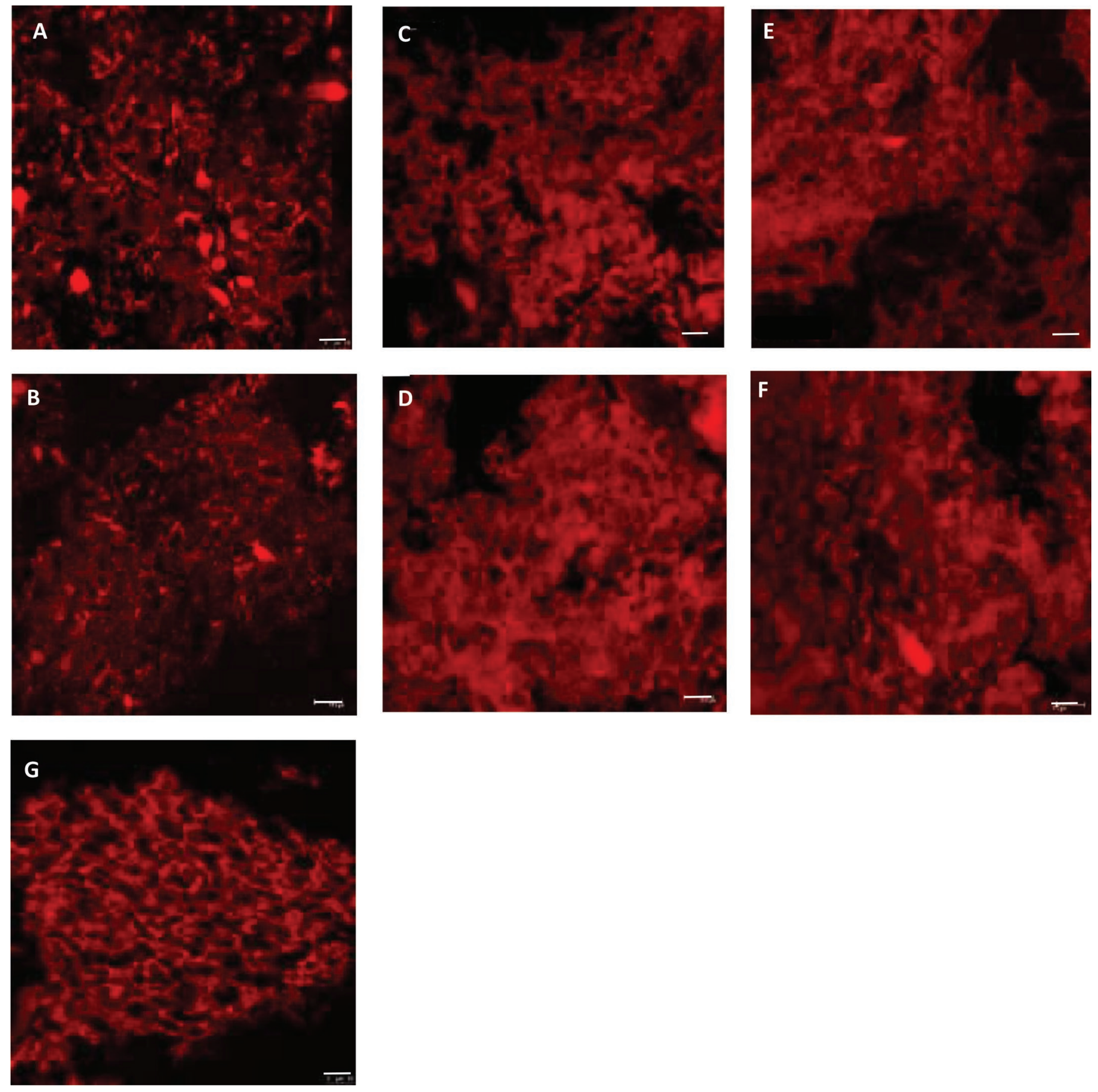

Figure 6. Confocal micrographs of the clots obtained after in vivo gastric digestion of model formula at 60 or 120 min postprandial. (A and B) whey protein (WP)-based formula at 60 and 120 min, respectively; (C and D) WP-casein based formula containing low $\beta$-CN:total casein ratio at 60 and $120 \mathrm{~min}$, respectively; (E and F) WP-casein based formula containing high $\beta$-CN:total casein ratio at 60 and 120 min, respectively; (G) clot obtained from suckling farm piglet (for comparison only). The scale bars represent $10 \mu \mathrm{m}$. Color version available online. 
postprandial. The digested gel matrix is strengthened by the casein-WP complexes formed during heating, which are known to form a gel at $\mathrm{pH}<5.5$ (Donato et al., 2007). It is important to note that in this study, a large WP:casein ratio was used compared with the ratio present in skim milk.

In addition to visual appearance, the gastric contents were analyzed using confocal microscopy. Figure 6 shows images representative of at least 3 piglets in each group of 4 . We observed profound differences in microstructure between the digesta obtained from WP and those from the WP-casein formula treatments. The digesta of the WP formula (Figure 6A and B) showed a porous structure with heterogeneous aggregates of different sizes. On the other hand, the digesta obtained from the WP-casein samples (Figure 6C, D, E, and F), regardless of $\beta-\mathrm{CN}$ ratio, showed a homogeneous network with large pores. Within a treatment, we observed no significant changes in microstructure in samples collected at 60 or $120 \mathrm{~min}$.

As a comparison, Figure $6 \mathrm{G}$ and $\mathrm{H}$ show the microstructure of digesta extracted from the stomach of suckling piglets. There were profound differences in their microstructure compared with that of digesta of formula-fed piglets. The clots from sow-fed pigs were characterized by a relatively homogeneous network with larger pores than those observed for the WP-casein clots. These differences correspond to the different protein composition of sow milk, as well as the higher fat content (Park and Haenlein, 2006b).

\section{Rheological Parameters}

The rheological parameters (viscosity and loss and storage moduli) for the 3 gastric digesta are given in Table 2. All digesta showed shear thinning behavior. The apparent viscosity of the WP formula-based digesta was significantly lower than that of the caseinWP mixtures, regardless of $\beta-\mathrm{CN}$ content. This may be due in part to the lower protein content in the digesta compared with the WP-casein systems, as shown in

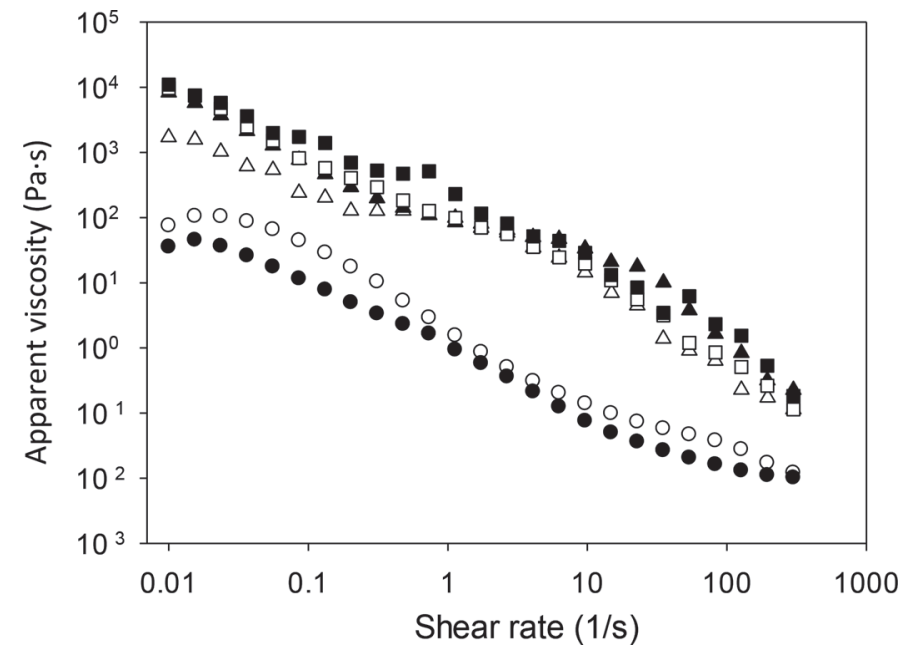

Figure 7. Apparent viscosity of digesta obtained from piglets at postprandial times of $60 \mathrm{~min}$ (open symbols) or $120 \mathrm{~min}$ (solid symbols). Piglets were fed with whey protein (WP)-based formula $(\mathrm{O}, \boldsymbol{\bullet})$ or WP-casein based formulas containing high $(\square, \boldsymbol{\square})$ or low $(\Delta, \boldsymbol{\Delta})$ $\beta-\mathrm{CN}$ :total casein ratio. For statistical analysis, see Table 2.

Figure 2. Viscosity values did not differ as a function of shear rate, within a treatment, between the samples collected after 60 or 120 min of digestion (Figure 7). The ratio of $\beta-\mathrm{CN}$ to other caseins did not affect the rheological behavior of the gastric digesta. Similar conclusions were drawn for the frequency sweep measurements. In this case, the storage and loss moduli of all gastric clots showed a weak frequency dependence for all the treatments, with $\mathrm{G}^{\prime}$ being dominant during the test, indicating a gel structure, as present in the stomach digesta. Both elastic and viscous moduli were significantly lower for the WP-based digesta than for the WP-casein digesta, with no significant differences between the samples containing high or low $\beta$-CN (Figure 8). These rheological findings complemented the visual observations in Figure 4 as well as the confocal graphs of the gastric digesta obtained from WP and WP-casein formula (Figure 6).

Table 2. Rheological properties of gastric digesta collected at postprandial times of 60 or 120 min $^{1}$

\begin{tabular}{|c|c|c|c|c|}
\hline \multirow[b]{2}{*}{ Formula } & \multicolumn{2}{|c|}{ Viscosity $(\mathrm{Pa} \cdot \mathrm{s})$} & \multirow{2}{*}{$\begin{array}{l}\text { Storage modulus } \mathrm{G}^{\prime} \\
(\mathrm{Pa}) \text { at } 120 \mathrm{~min}\end{array}$} & \multirow{2}{*}{$\begin{array}{l}\text { Loss modulus } \mathrm{G}^{\prime \prime} \\
(\mathrm{Pa}) \text { at } 120 \mathrm{~min}\end{array}$} \\
\hline & $60 \min$ & $120 \min$ & & \\
\hline WP-based & $0.16 \pm 0.02^{\mathrm{d}}$ & $0.08 \pm 0.01^{\mathrm{d}}$ & $18 \pm 2.3^{\mathrm{b}}$ & $5 \pm 0.78^{b}$ \\
\hline Low $\beta$-casein & $22.7 \pm 8.3^{\mathrm{c}}$ & $35.6 \pm 9.2^{\mathrm{c}}$ & $2,622 \pm 923^{\mathrm{a}}$ & $1,077 \pm 375^{\mathrm{a}}$ \\
\hline High $\beta$-casein & $19.0 \pm 0.75^{\mathrm{c}}$ & $27.4 \pm 3.2^{\mathrm{c}}$ & $2,022 \pm 432^{\mathrm{a}}$ & $831 \pm 175^{\mathrm{a}}$ \\
\hline
\end{tabular}




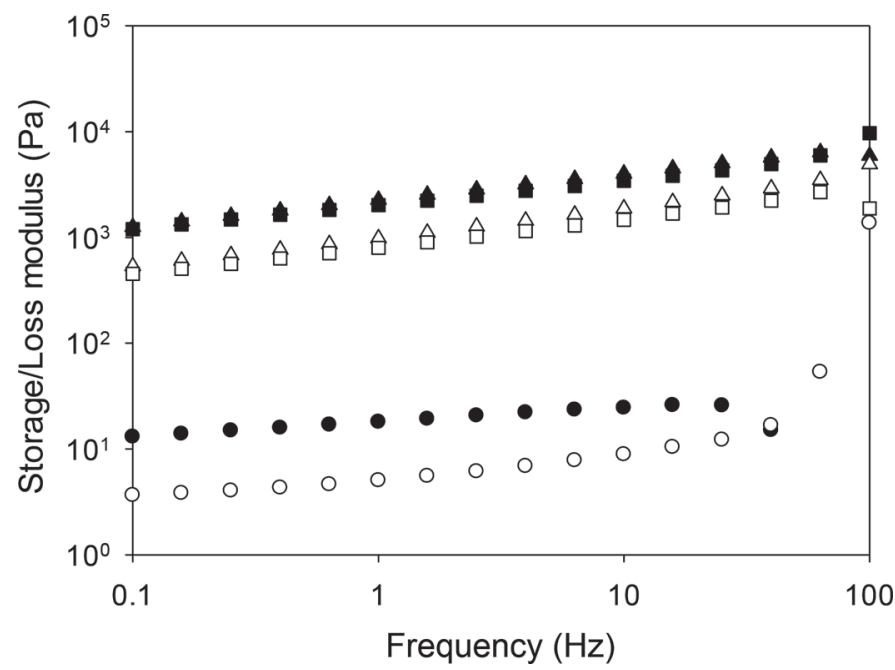

Figure 8. Frequency dependence of storage $\left(\mathrm{G}^{\prime}\right.$, sold symbols $)$ and loss $\left(\mathrm{G}^{\prime \prime}\right.$, open symbols) moduli of the digesta obtained from piglets at 120 min postprandial. Piglets were fed a whey protein (WP)-based formula $(O ; \bullet)$ or WP-casein based formulas containing high $(\square, \boldsymbol{\square})$ or low $(\Delta, \mathbf{\Delta}) \beta$-CN:total casein ratio.

\section{CONCLUSIONS}

Our results indicated significant differences between gastric digestion patterns of caseins and WP in a piglet model. The findings suggest that although caseins and their peptides precipitate and form a homogeneous, firm clot during gastric digestion in the presence of pepsin, WP are resistant to hydrolysis in the gastric environment and a large portion is found soluble in the gastric digesta. The microstructure of the gastric digested mixture and the viscoelastic properties did not change with postprandial time. The $\mathrm{pH}$ values recorded at 60 and 120 min after the last meal varied between 4.4 and 5.8, indicating that the type of clot for these model formulas is a mixed acid/enzymatic-induced gel consisting of intact WP and residual caseins. The gastric digesta of piglets consuming the WP formula had lower viscosity and a more heterogeneous microstructure than that obtained from piglets on the WP-casein formula. The differences in $\beta$-CN ratio tested in this study did not affect the physical properties of the clots.

\section{ACKNOWLEDGMENTS}

The authors thank Michaela Strüder-Kypke (University of Guelph Imaging Center) for her expert assistance with confocal laser scanning microscopy, and the students and staff who assisted with diet manufacturing, animal care and surgery procedures. This work was funded by the Natural Sciences and Engineering Council of Canada, through Canada Research Chair program in Nanostructure and the Canadian Dairy Commission through a scholarship to NRT.

\section{REFERENCES}

Boirie, Y., M. Dangin, P. Gachon, M. P. Vasson, J. L. Maubois, and B. Beaufrere. 1997. Slow and fast dietary proteins differently modulate postprandial protein accretion. Proc. Natl. Acad. Sci. USA 94:14930-14935.

Bouzerzour, K., F. Morgan, I. Cuinet, C. Bonhomme, J. Jardin, I. Le Huërou-Luron, and D. Dupont. 2012. In vivo digestion of infant formula in piglets: Protein digestion kinetics and release of bioactive peptides. Br. J. Nutr. 108:2105-2114.

Chatelais, L., A. Jamin, C. Gras-Le Guen, J. P. Lalles, I. Le HuerouLuron, and G. Boudry. 2011. The level of protein in milk formula modifies ileal sensitivity to LPS later in life in a piglet model. PLoS One 6:e19594.

Chatterton, D. E. W., J. T. Rasmussen, C. W. Heegaard, E. S. Sørensen, and T. E. Petersen. 2004. In vitro digestion of novel milk protein ingredients for use in infant formulas: Research on biological functions. Trends Food Sci. Technol. 15:373-383.

Creamer, L. K., G. P. Berry, and O. E. Mills. 1977. A study of the dissociation of $\beta$-casein from the bovine casein micelle at low temperature. N.Z. J. Dairy Sci. Technol. 12:58-66.

Dalgleish, D. G., and M. Corredig. 2012. The structure of the casein micelle of milk and its changes during processing. Annu. Rev. Food Sci. Technol. 3:449-467.

Darragh, A. J., and P. J. Moughan. 1995. The three-week-old piglet as a model animal for studying protein digestion in human infants. J. Pediatr. Gastroenterol. Nutr. 21:387-393.

Donato, L., M. Alexander, and D. G. Dalgleish. 2007. Acid gelation in heated and unheated milks: Interactions between serum protein complexes and the surfaces of casein micelles. J. Agric. Food Chem. 55:4160-4168.

Hall, W. L., D. J. Millward, S. J. Long, and L. M. Morgan. 2003. Casein and whey exert different effects on plasma amino acid profiles, gastrointestinal hormone secretion and appetite. Br. J. Nutr. $89: 239-248$.

Holland, B., M. Corredig, and M. Alexander. 2011. Gelation of casein micelles in $\beta$-casein reduced milk prepared using membrane filtration. Food Res. Int. 44:667-671.

Holland, B., S. Rahimi Yazdi, G. Ion Titapiccolo, and M. Corredig. 2010. Short communication: Separation and quantification of caseins an casein macropeptide using ion-exchange chromatography. J. Dairy Sci. 93:893-900.

Kim, C. J., J. Kovacs-Nolan, C. Yang, T. Archbold, M. Z. Fan, and Y. Mine. 2009. L-Cysteine supplementation attenuates local inflammation and restores gut homeostasis in a porcine model of colitis. Biochim. Biophys. Acta 1790:1161-1169.

Korhonen, H., and A. Pihlanto. 2006. Bioactive peptides: Production and functionality. Int. Dairy J. 16:945-960.

Le Feunteun, S., F. Barbé, D. Rémond, O. Ménard, Y. Le Gouar, D. Dupont, and B. Laroche. 2014. Impact of the dairy matrix structure on milk protein digestion kinetics: Mechanistic modelling based on mini-pig in vivo data. Food Bioprocess Technol. 7:1099-1113.

Mahé, S., N. Roos, R. Benamouzig, L. Davin, C. Luengo, L. Gagnon, N. Gausserges, J. Rautureau, and D. Tome. 1996. Gastrojejunal kinetics and the digestion of $\left.{ }^{15} \mathrm{~N}\right] \beta$-lactoglobulin and casein in humans: The influence of the nature and quantity of the protein. Am. J. Clin. Nutr. 63:546-552.

Mason, S. 1962. Some aspects of gastric function in newborn. Arch Dis. Child. 37:387-391.

Miller, E. R., and D. E. Ullrey. 1987. The pig as a model for human nutrition. Annu. Rev. Nutr. 7:361-382.

Miranda, G., and J. P. Pelissier. 1983. Kinetic studies of in vivo digestion of bovine unheated skim-milk proteins in the rat stomach. J. Dairy Res. 50:27-36. 
Moughan, P. J., P. D. Cranwell, and W. C. Smith. 1991. An evaluation with piglets of bovine milk, hydrolyzed bovine milk, and isolated soybean proteins included in infant milk formulas. II. Stomach emptying rate and the postprandial change in gastric $\mathrm{pH}$ and milk clotting enzyme activity. J. Pediatr. Gastroenterol. Nutr. 12:253-259.

Park, Y. W., and G. F. W. Haenlein. 2006a. Human milk. Pages 407420 in Human Handbook of Milk of Non-Bovine Mammals. 1st ed. Y. W. Park and G. F. W. Haenlein, ed. Blackwell Pub., Ames, IA.

Park, Y. W., and G. F. W. Haenlein. 2006b. Sow milk. Pages 371-381 in Human Handbook of Milk of Non-Bovine Mammals. 1st ed. Y. W. Park and G. F. W. Haenlein, ed. Blackwell Pub., Ames, IA.

Perrella, S. L., A. R. Hepworth, Z. Gridneva, K. N. Simmer, P. E. Hartmann, and D. T. Geddes. 2015. Gastric emptying and curding of pasteurized donor human milk and mother's own milk in preterm infants. J. Pediatr. Gastroenterol. Nutr. 61:125-129.

Rioux, L. E., and S. L. Turgeon. 2012. The ratio of casein to whey protein impacts yogurt digestion in vitro. Food Dig. 3:25-35.
Sah, B. N. P., A. J. McAinch, and T. Vasiljevic. 2016. Modulation of bovine whey protein digestion in gastrointestinal tract: A comprehensive review. Int. Dairy J. 62:10-18.

Tam, J. J., and J. R. Whitaker. 1972. Rates and extents of hydrolysis of several caseins by pepsin, rennin, endothia parasitita protease and mucor pusillus protease. J. Dairy Sci. 55:1523-1531.

Theil, P. K., and W. L. Hurley. 2016. The protein component of sow colostrum and milk. Pages 183-195 in Milk Proteins-From Structure to Biological Properties and Health Aspects. I. Gigli, ed. InTech, Rijeka, Croatia.

Thompkinson, D. K., and S. Kharb. 2007. Aspects of infant food formulation. Compr. Rev. Food Sci. Food Saf. 6:79-102.

Turgeon, S. L., and L. E. Rioux. 2011. Food matrix impact on macronutrients nutritional properties. Food Hydrocoll. 25:1915-1924.

Ye, A., J. Cui, D. Dalgleish, and H. Singh. 2016. Formation of a structured clot during the gastric digestion of milk: Impact on the rate of protein hydrolysis. Food Hydrocoll. 52:478-486. 